\title{
Tecnologia a serviço da ciência
}

\author{
Domingo M. BRAILE*
}

A s revistas científicas são exemplo da integração entre ciência e tecnologia. Desde as publicações pioneiras, no século XVII, a troca de informações entre pares vem passando por inúmeras transformações. Se antes a informação levava meses para ser disponibilizada, agora bastam alguns cliques no mouse para se acessar um artigo antes mesmo de ele ser publicado. E as perspectivas são inimagináveis, tal a evolução constante da informática.

A Revista Brasileira de Cirurgia Cardiovascular/Brazilian Journal of Cardiovascular Journal (RBCV/BJCVS) é um exemplo disso. Teve início como periódico quadrimestral, em 1986, e depois passou a trimestral. Em 1997, começou a ser disponibilizada na Internet, pela Scielo, e em 2005 ganhou seu próprio site.

Neste volume, damos mais um passo adiante ao disponibilizarmos, pela primeira vez, aos associados da Sociedade Brasileira de Cirurgia Cardiovascular (SBCCV), e demais estudiosos e instituições que recebem a revista, um "brinde” especial. Um DVD mostrando uma operação cavo-pulmonar total, com tubo extra-cardíaco, sem circulação extracorpórea realizada pelo Editor Associado Ulisses Alexandre Croti, em colaboração comigo. Assim, além do relato por escrito, na página 429, o leitor terá a oportunidade de ver o desenrolar do procedimento, o que certamente agregará conhecimento e despertará muito interesse. O vídeo também estará disponível no site da RBCCV, no link http://www.rbccv.org.br/video/ Cavopulmonar_total.asp .

A idéia é de que a iniciativa se repita nas futuras edições. E, desde já, conclamo aos colegas que tiverem casos interessantes registrados em vídeo para entrar em contato conosco a fim de viabilizar uma futura inserção. Infelizmente, tecnologia tem custo e para torná-la viável teremos que contar com novas fontes de suporte econômico.

O site da revista (www.rbccv.org.br) continua sendo aperfeiçoado. A fim de que sejam somente enviadas figuras com resolução compatível com a determinada pelas Normas da Revista (300 dpis) serão bloqueadas imagens com resolução mais baixa, que prejudicam a qualidade da edição impressa. Em breve, o sistema recusará descritores (palavras-chaves) que não constem do DeCs (Descritores em Ciências da Saúde) e do Mesh (Medical Subject Headings), impedindo que a submissão avance enquanto não forem colocados termos corretos. Lembro que o site tem um link para o DeCs e o Mesh, para facilitar o autor durante a montagem do manuscrito. Estas mudanças permitem um maior controle da qualidade da RBCCV, fundamental para que continuemos indexados no Medline e obtenhamos indexação em outras bases de dados, como a Reuters.

Também estamos ultimando os preparativos para implantar o sistema de Educação Médica Continuada (EMC) online, conforme informei no editorial do volume 23.2. Ao acessar o site, haverá um determinado número de artigos marcados com um ícone, com a sigla (EMC). Ao clicar sobre ele, será aberto um questionário com perguntas sobre o conteúdo. Após respondê-lo, e se as respostas estiverem corretas, será emitido um certificado, que contará pontos para obtenção e revalidação do Título (sujeito ainda a aprovação). O leitor poderá responder as perguntas até acertá-las todas, dentro de um tempo limitado a incrementos de 15 minutos no prazo total de uma hora. Quando atingir este estágio, a resposta certa ficará evidente e o candidato poderá acessar o texto no qual estarão em evidência os parágrafos de onde foram geradas as perguntas. Este tipo de educação continuada é pró-ativa e não visa reprovar ninguém, mas sim incentivar que os artigos sejam lidos e compreendidos.

Nos dias 14 e 15 de agosto, tivemos uma produtiva reunião com o Programador Sr. Daniel Marcoto, representante da GN1, empresa que opera o nosso site. Participaram comigo desta reunião o Dr. Ulisses Alexandre Croti, Editor Associado da RBCCV e o Editor Executivo, Sr. Ricardo Brandau, cuja colaboração efetiva muito agradeço. Pudemos navegar no "piloto" do novo sistema. Foram feitos testes e dadas sugestões para aperfeiçoar a ECM; pareceunos que está pronta para ser implantada, o que desejamos fazer em breve. Para esta nova modalidade de ensino será fundamental a qualidade dos artigos e a colaboração dos autores para fazerem as perguntas que serão oferecidas aos candidatos.

Esta iniciativa, pioneira em nosso país, é mais uma prova de que o Brasil pode perder o "complexo de vira-lata", como dizia o dramaturgo e escritor Nelson Rodrigues, frente aos chamados países do Primeiro Mundo quando o assunto é ciência e tecnologia. Números divulgados pelo Ministério da Educação e Capes, em julho, confirmaram a produção científica brasileira como a $15^{\text {a }}$ do mundo em 2007, patamar atingido no ano anterior.

Com 19.428 artigos publicados em 2007, o país responde 
por 2,02\% do total da produção científica no mundo, superando a Suíça $(1,89 \%)$ e a Suécia $(1,81 \%)$ e perto da Holanda (2,55\%) e da Rússia (2,66\%). Entre os países latinoamericanos, posição é ainda mais destacada. A nação que aparece em segundo lugar é o México, na $28^{a}$ posição mundial, com 7.469 artigos publicados no mesmo período, o que corresponde a $0,78 \%$ da produção no mundo. Para nosso orgulho, as Ciências da Saúde são os principais atores deste desafiante campeonato! A Medicina continua sendo destaque, especialmente na produção interna: 3.745 artigos publicados em 2007.

O presidente da Capes, Prof. Jorge Guimarães, destacou alguns dos motivos para a boa colocação do país: programas de iniciação científica, fortalecimento da pósgraduação, formação de grupos de pesquisa, cooperações internacionais e o Portal de Periódicos da Capes, que oferece gratuitamente mais de 12 mil periódicos para as Universidades e Centros de Pesquisa. "O mundo dobrou a produção científica de 1981 a 2006. O Brasil aumentou-a em nove vezes”, disse ele.

Mas estes números positivos não devem fazer com que deitemos em berço esplêndido e joguemos os problemas para debaixo do tapete. Texto do professor Saul Goldenberg, publicado originalmente no site da Associação Brasileira de Editores Científicos (ABEC) e que reproduzimos na no Editorial da página VIII, relata as dificuldades pelas quais passou como Editor da Acta Cirúrgica Brasileira. Dificuldades estas que em maior ou menor grau são sentidas por todos os Editores no Brasil. Recomendo a leitura atenta daquele excelente relato.
Ainda como alerta aos autores e revisores, a RBCCV reproduz, na página 396, um artigo, escrito pelo Dr. Mário José da Conceição e publicado originalmente na Revista Brasileira de Anestesiologia, enfatizando os equívocos que o uso incorreto da estatística pode provocar nos trabalhos científicos.

Temos mais dois editoriais nesta edição, com temas de grande interesse para os cirurgiões cardiovasculares. Em um deles, na página IX, o Dr. Telmo Martino Bonamigo discorre sobre os benefícios da endarterectomia carotídea. Na página III, os Drs. Domingos Sávio de Souza e Walter Gomes discutem sobre o futuro da veia safena como conduto na revascularização miocárdica.

E, antes de encerrar, gostaria de chamar a atenção dos colegas para o Memorial sobre o já saudoso Dr. José Carlos de Andrade, escrito pelo Prof. Antonio Carlos Carvalho, da Unifesp, na página 315. São emocionadas e marcantes palavras sobre a vida e o trabalho deste dedicado médico, que, mesmo lutando contra um câncer, continuou exercendo com denodo a sua profissão, deixando um exemplo para sua família, seus amigos e seguidores.

Recebam meu abraço,

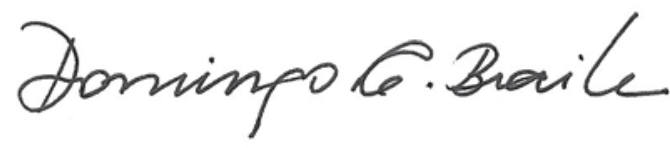

*Editor - RBCCV 